\title{
FRAMEWORK TO ASSIST INVESTMENT PORTFOLIO GENERATION FOR FINANCIAL SECTOR
}

Versão do autor aceita publicada online: 22 maio 2021

Publicado online: 30 jun. 2021

Como citar esse artigo - American Psychological Association (APA): Carmo, B. B. T., Medeiros, P. P. M., Gonçalo, T. E. E., \& Correia, G. C. (2021). Framework to assist investment portfolio generation for financial sector. Exacta. DOI: https://doi.org/10.5585/exactaep.2021.18687.

\section{Breno Barros Telles do Carmo}

https://orcid.org/0000-0002-7506-7037

Universidade Federal Rural do Semiárido

Professor of Industrial and Mechanical Engineering courses at Engineering Centre of Federal University of the Semi-Arid Region (UFERSA), Brazil. Professor of Ambient, Technology and Society (PPGATS) and Cognition, Technology and Institutions (PPGCTI) master programs. Head of Engineering and Environmental Sciences Department (DECAM). Head of Healthcare Operations Management research group (GOSS). Consultant for evaluation of undergraduate courses (INEP/MEC), Brazil. Member of SLCAlliance for revisions of SLCA Guidelines (UNEP). Bachelor in Industrial Engineering from Federal University of Ceará (UFC), with a stage at Porto University (UP), Portugal, (2003-2007), supported by UP scholarship. Master degree in Transportation Engineering from Federal University of Ceará (2008-2009), supported by Capes scholarship. Ph.D in Industrial Engineering (Department of Mathematics and Industrial Engineering) from École Polytechnique de Montréal (2013-2017), Université de Montréal, Canada, supported by Capes scholarship, with a stage at Université Libre de Bruxelles (ULB), Belgium. The research themes are focused on sustainability, life cycle assessment, decision-making, healthcare operations, transportation and engineering education.

\section{Pablo Picasso Morais de Medeiros}

https://orcid.org/0000-0002-0879-340X

Universidade Federal Rural do Semiárido

Possui graduação em Engenharia de Produção pela Universidade Federal Rural do Semi-Árido (2019) e graduação em Ciência e Tecnologia pela Universidade Federal Rural do Semi-Árido (2017).

\section{Thomas Edson Espíndola Gonçalo}

https://orcid.org/0000-0003-4430-9547

Universidade Federal Rural do Semiárido (UFERSA)

Engenheiro de Produção pela Universidade Federal do Vale do São Francisco (UNIVASF). Doutor e Mestre em Engenharia de Produção pelo Programa de Pós-Graduação em Engenharia de Produção (PPGEP) da Universidade Federal de Pernambuco. Atuei como Analista e Gerente de Logística nas Lojas Americanas S/A, atuando na área de gestão de Centro de Distribuição. Atualmente Professor Adjunto do curso de Engenharia de Produção da Universidade Federal Rural do Semi-Árido (UFERSA), campus Mossoró-RN. Realizo pesquisas na área de Pesquisa Operacional, especificamente na área de Apoio à tomada de decisão multicritério, tomada de decisão em grupo e negociação, com aplicações voltadas para procurement, gestão de recursos hídricos e gestão pública.

\section{Gabriela Colaço Correia}

https://orcid.org/0000-0001-9281-5829

Universidade Federal Rural do Semiárido

Possui graduação em Engenharia de Produção pela Universidade Federal Rural do Semi-Árido (2019) e graduação em Ciência e Tecnologia pela Universidade Federal Rural do Semi-Árido (2017). 
internal and external factors that may influence the success of the organization (BOVESPA, 2019).

On the other hand, day trade investors analyze short-term fluctuations in stock market quotations, seeking to sell stocks at a value higher than the acquisition price (BOVESPA, 2019). Gomes (2018) compared the two strategies (called A and B) most commonly used by day trade investors and the performance of a stock portfolio based on fundamentalist analysis. The study showed that strategies A and B (both day trade) yielded a negative return of $-5.34 \%$ and $-6.51 \%$, respectively, whereas the portfolio based on fundamentalist analysis yielded a positive return of $18,33 \%$ in the same period.

Considering the challenges and limitations shown by Chague and Giovanneti (2019) and Gomes (2018) regarding day trade investments based on technical analysis, this study will be conducted through the fundamentalist approach to stock market valuation, focused on multivariate and financial analysis.

Regardless of the strategy used, it should be noted that there is an inherent risk in the stock market. In the Brazilian market, a company's risk is assessed based on the variance of its share price around the Bovespa - Ibovespa index, and such risk is expressed by “ $\beta$ ”, calculated and provided by financial information systems (Kobori, 2019):

- $\beta=1$ That means that the share price strictly follows the Bovespa index;

- $\beta<1$ That means that the stock has less variability than the Bovespa index. Thus, if the company's beta is 0.5 , a $10 \%$ Ibovespa change will result in a change and only $5 \%$ in the company's quotation;

- $\beta>1$ That means that the stock has more significant variability than the Bovespa index. Thus, if the company's beta is 1.8 , a $10 \%$ Ibovespa change will result in an $18 \%$ change the company's quotation.

Due to the complexity of the valuing companies, the high volume of resources present in stock market operations and the risks inherent in the stock market, it is necessary to use tools that assist the investor in making decisions about the stocks / in which it should allocate its capital (Vidotto et al., 2009). According to Luquet (2007), many variables can influence the movements of the economy and the performance of stocks in the financial market, such as corporate results, price stocks, interest rates, exchange rates and inflation.

To identify existing gaps and opportunities for improvement in the models currently used for investment portfolio selection, a search was conducted in order to identify the financial 
institutions, regulated by the CVM (Brazilian Securities and Exchange Commission - in portuguese), that provide a recommended stock portfolio free of charge, that means, no subscription, registration or other payment required. As such, 14 institutions were considered for evaluation. Table 1 presents the criteria used when recommending investment portfolios. It is possible to identify the characteristics in common among these portfolios and the gaps in the recommendations provided.

Table 1: Characteristics of recommended portfolios.

\begin{tabular}{|l|c|c|c|c|c|c|c|c|}
\hline \multicolumn{1}{|c|}{ Institution } & $\begin{array}{c}\text { Long- } \\
\text { term } \\
\text { focus? }\end{array}$ & $\begin{array}{c}\text { Segmented } \\
\text { by sector? }\end{array}$ & $\begin{array}{c}\text { Is there a } \\
\text { minimum } \\
\text { performance } \\
\text { filter? }\end{array}$ & $\begin{array}{c}\text { Is it a } \\
\text { formal } \\
\text { method? }\end{array}$ & $\begin{array}{c}\text { Is it an } \\
\text { open } \\
\text { method? }\end{array}$ & $\begin{array}{c}\text { Size of } \\
\text { portfolio }\end{array}$ & $\begin{array}{c}\text { Does it } \\
\text { indicate the } \\
\%\end{array}$ & $\begin{array}{c}\text { Is it ân } \\
\text { open } \\
\text { method of } \\
\text { allocation? }\end{array}$ \\
\hline $\begin{array}{l}\text { XP } \\
\text { Investimentos }\end{array}$ & $\mathrm{Y}$ & $\mathrm{N}$ & $\mathrm{Y}$ & $\mathrm{N} . \mathrm{I}$ & $\mathrm{N}$ & 5 & $\mathrm{~N}$ & $\mathrm{~N}$ \\
\hline Toro Radar & $\mathrm{NI}$. & $\mathrm{N}$ & $\mathrm{N} . \mathrm{I}$ & $\mathrm{N} . \mathrm{I}$ & $\mathrm{N}$ & 5 & $\mathrm{Y}$ & $\mathrm{N}$ \\
\hline $\begin{array}{l}\text { Rico } \\
\text { Investimentos }\end{array}$ & $\mathrm{Y}$ & $\mathrm{N}$ & $\mathrm{N}$ & $\mathrm{NI}$. & $\mathrm{N}$ & 12 & $\mathrm{Y}$ & $\mathrm{N}$ \\
\hline BTG Pactual & $\mathrm{N} . \mathrm{I}$. & $\mathrm{N}$ & $\mathrm{N} . \mathrm{I}$ & $\mathrm{N} . \mathrm{I}$ & $\mathrm{N}$ & 6 & $\mathrm{Y}$ & $\mathrm{N}$ \\
\hline $\begin{array}{l}\text { Elite } \\
\text { Investimentos }\end{array}$ & $\mathrm{NI}$. & $\mathrm{N}$ & $\mathrm{NI}$. & $\mathrm{NI}$. & $\mathrm{N}$ & 11 & $\mathrm{~N}$ & $\mathrm{~N}$ \\
\hline $\begin{array}{l}\text { Terra } \\
\text { Investimentos }\end{array}$ & $\mathrm{Y}$ & $\mathrm{N}$ & $\mathrm{N}$ & $\mathrm{N} . \mathrm{I}$ & $\mathrm{N}$ & 7 & $\mathrm{~N}$ & $\mathrm{~N}$ \\
\hline Necton & $\mathrm{Y}$ & $\mathrm{N}$ & $\mathrm{N}$ & $\mathrm{NI}$ & $\mathrm{N}$ & 10 & $\mathrm{Y}$ & $\mathrm{N}$ \\
\hline $\begin{array}{l}\text { Genial } \\
\text { Investimentos }\end{array}$ & $\mathrm{Y}$ & $\mathrm{N}$ & $\mathrm{Y}$ & $\mathrm{NI}$. & $\mathrm{N}$ & 10 & $\mathrm{Y}$ & $\mathrm{N}$ \\
\hline $\begin{array}{l}\text { Nova Futura } \\
\text { Corretora }\end{array}$ & $\mathrm{N} . \mathrm{I}$ & $\mathrm{N}$ & $\mathrm{N}$ & $\mathrm{N}$ & $\mathrm{N}$ & 10 & $\mathrm{Y}$ & $\mathrm{N}$ \\
\hline $\begin{array}{l}\text { BB } \\
\text { Investimentos }\end{array}$ & $\mathrm{N} . \mathrm{I}$ & $\mathrm{N}$ & $\mathrm{N}$ & $\mathrm{N}$ & $\mathrm{N}$ & 10 & $\mathrm{~N}$ & $\mathrm{~N}$ \\
\hline $\begin{array}{l}\text { Planner } \\
\text { Corretora }\end{array}$ & $\mathrm{Y}$ & $\mathrm{N}$ & $\mathrm{N}$ & $\mathrm{N}$ & $\mathrm{N}$ & 5 & $\mathrm{~N}$ & $\mathrm{~N}$ \\
\hline $\begin{array}{l}\text { Coinvalores } \\
\text { Ativa } \\
\text { investimentos }\end{array}$ & $\mathrm{Y}$ & $\mathrm{N}$ & $\mathrm{N}$ & $\mathrm{NI}$. & $\mathrm{N}$ & 10 & $\mathrm{Y}$ & $\mathrm{N}$ \\
\hline Modal Mais & $\mathrm{N} . \mathrm{I}$ & $\mathrm{N}$ & $\mathrm{Y}$ & $\mathrm{N}$ & $\mathrm{N}$ & 5 & $\mathrm{~N}$ & $\mathrm{~N}$ \\
\hline
\end{tabular}

Legend: Y - YES; N - NO; N.I - Not informed.

Source: The authors (2019) 
It is worth mentioning that the researched institutions carry out, in their recommended portfolio, a brief analysis of recent economic aspects that may impact the business of each indicated company. Although relevant for the analysis of the company and its sector, these data do not fully explain the reason for choosing a stock. Institutions do not clearly state the criteria for selecting the recommended portfolio.

These investment agents assert that portfolios are selected based on some generic guidelines, without, however, explaining how stocks are chosen from all assets that meet these guidelines. To exemplify the generalism mentioned, we highlight below an excerpt taken from the XP investments website:

"The main characteristics that we look for in the portfolio's securities are: a) The prospect of continuous dividend payment and an attractive yield, that is, that they pay a dividend in $\%$ of the attractive and recurring share price; b) Companies that have a quality management and operate a solid business, as this is essential for the payment of dividends to be sustainable; and c) Companies of a more defensive nature, important for the continuous flow of dividends, but which are in an interesting entry point, seeking portfolio appreciation (Luketic, 2019)."

The same research was conducted to identify academic studies related to the present work through a search at Scielo and Google Scholar using the terms multicriteria, stock, and investment portfolio. Table 2 presents a summary of the main characteristics of the works found.

Table 2: Characteristics of searched works.

\begin{tabular}{|l|l|l|l|l|l|l|l|}
\hline Reference & $\begin{array}{c}\text { Long- } \\
\text { term } \\
\text { focus? }\end{array}$ & $\begin{array}{c}\text { Specific } \\
\text { to a } \\
\text { sector? }\end{array}$ & $\begin{array}{c}\text { Is there a } \\
\text { minimum } \\
\text { performance } \\
\text { filter? }\end{array}$ & $\begin{array}{c}\text { Does it } \\
\text { generate a } \\
\text { ranking? }\end{array}$ & $\begin{array}{c}\text { Does it } \\
\text { generate a } \\
\text { portfolio? }\end{array}$ & $\begin{array}{c}\text { Does it } \\
\text { Type of } \\
\text { method used }\end{array}$ & $\begin{array}{c}\text { indicate } \\
\text { the \% } \\
\text { allocation } \\
?\end{array}$ \\
\hline Gomes (2018) & $\mathrm{N}$ & $\mathrm{N}$ & $\mathrm{N}$ & $\mathrm{N}$ & $\mathrm{N}$ & $\begin{array}{l}\text { Technical } \\
\text { Analysis }\end{array}$ & $\mathrm{N}$ \\
\hline Daibert (2016) & $\mathrm{N}$ & $\mathrm{N}$ & $\mathrm{N}$ & $\mathrm{N}$ & $\mathrm{N}$ & Interview & $\mathrm{N}$ \\
\hline
\end{tabular}




\begin{tabular}{|c|c|c|c|c|c|c|c|}
\hline $\begin{array}{l}\text { Malta \& De Camargos } \\
\text { (2016) }\end{array}$ & $\mathrm{Y}$ & $\mathrm{N}$ & $\mathrm{N}$ & $\mathrm{N}$ & $\mathrm{N}$ & $\begin{array}{l}\text { Fixed-effect } \\
\text { model }\end{array}$ & $\mathrm{N}$ \\
\hline Lima et al. (2006) & $\mathrm{N}$ & $\mathrm{N}$ & $\mathrm{N}$ & $\mathrm{N}$ & $\mathrm{N}$ & SMARTER & $\mathrm{N}$ \\
\hline $\begin{array}{l}\text { Da Costa \& Júnior } \\
\text { (2013) }\end{array}$ & $\mathrm{N}$ & $\mathrm{N}$ & $\mathrm{N}$ & $Y$ & $\mathrm{~N}$ & TOPSIS & $\mathrm{N}$ \\
\hline $\begin{array}{l}\text { Sant'Anna, Nogueira } \\
\text { e\&Rabelo (2012) }\end{array}$ & $\mathrm{N}$ & $\mathrm{N}$ & $\mathrm{N}$ & $\mathrm{Y}$ & $\mathrm{Y}$ & $\begin{array}{l}\text { TOPSIS and } \\
\text { CPP }\end{array}$ & $\mathrm{N}$ \\
\hline Paixão (2013) & $\mathrm{Y}$ & $\mathrm{N}$ & $\mathrm{N}$ & $Y$ & $\mathrm{~N}$ & AHP & $\mathrm{N}$ \\
\hline Silva (2018) & $\mathrm{N}$ & $\mathrm{N}$ & $\mathrm{N}$ & $\mathrm{N}$ & $\mathrm{N}$ & TOPSIS & $\mathrm{N}$ \\
\hline Lyrio et al. (2015) & $\mathrm{Y}$ & $\mathrm{N}$ & $\mathrm{Y}$ & $\mathrm{N}$ & $S$ & SMARTER & $\bar{N}$ \\
\hline $\begin{array}{l}\text { Vezmelai, Lashgari \& } \\
\text { Keyghobadi (2015) }\end{array}$ & $\mathrm{N}$ & $\mathrm{N}$ & $\mathrm{N}$ & $\mathrm{Y}$ & $\mathrm{N}$ & ELECTRE III & \\
\hline $\begin{array}{l}\text { Xidonas, Mavrotas \& } \\
\text { Psarras (2009) }\end{array}$ & $\mathrm{N}$ & $\mathrm{N}$ & $\mathrm{N}$ & $\mathrm{N}$ & Y & & $\mathrm{N}$ \\
\hline Mehlawat (2016) & $\mathrm{N}$ & $\mathrm{N}$ & $\mathrm{N}$ & $\mathrm{N}$ & $\mathrm{Y}$ & AHP & $\mathrm{N}$ \\
\hline
\end{tabular}

Legend: Y - YES; N - NO; N.I - Not informed.

Source: Authors' compilation (2019)

We found that $75 \%$ of the publications evaluated present methods for operations that aim at short-term gains due to stock price fluctuations, and these methods are suitable for day trade investors. Thus, these models do not analyze financial and economic data of companies.

Thus, it should be noted that among the studies analyzed, only three studies focus on fundamentalist analysis, of which only two use multicriteria models for the selection of stocks. The models used by these searches are AHP and SMARTER, both compensatory methods.

We emphasize that compensatory models can distort the results since they allow alternatives with high performance in one criterion to use their score in this criterion to compens ate for poor performances in the other criteria, as discussed in Jeffreys (2004) and Banihabib, HashemiMadani and Forghani (2017). Finally, we also highlight that the researched works do not indicate a specific financial sector portfolio. Also, none of the publications indicate a method for capital allocation after portfolio definition. Thus, in the methods presented in Table 5, there is a discretionary decision of the investor as to the percentage of participation of each share in its portfolio. We emphasize that the absence of an accurate and consistent allocation and capital method may undermine the return on investments.

As such, this paper aims to fulfill this research gap associated with the tools for analysing investment portfolios, proposing an approach able to select companies of the financial sector when generating investment portfolios. Besides, our approach establishes the minimum 
acceptable performances for the stocks included in the portfolio through the filtering process step. Finally, the model is able to define the capital allocation among the companies included in the portfolio. This approach was implemented through PROMETHEE V technique and a supplementary step based on linear programming.

Thus, due to the various characteristics inherent in stock market choice, the present study proposes a framework to assist investors in generating an investment portfolio in financial sector companies considering fundamentalist asset analysis.

\section{METHODOLOGY}

The research methodology used in the present study followed the steps proposed by Shärlig (1985) to conduct multicriteria decision support modeling: 01) to define the list of potential alternatives; 02) choose the performance measurement criteria, 03) measure the performance of the alternatives in each criterion, 04) aggregate the results, 05) define the portfolio that represents the best possible performance according to the criteria, weights and thresholds - preferably defined. Finally, we proposed an additional step " 06 " to define the number of shares to be purchased from each portfolio alternative. Thus, Figure 2 illustrates the stages and activities foreseen in developing the approach proposed in this research. 
Figure 2: Research Stages

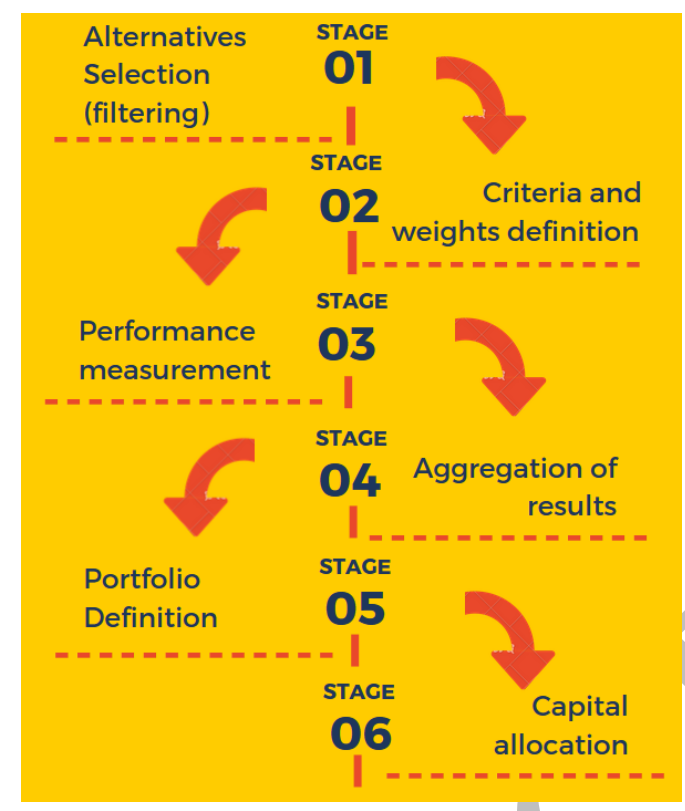

Source: The authors (2019)

\subsection{Selection of potential alternatives}

Stage 01 consists of selecting the alternatives that will be evaluated by the proposed framework. To this end, filters have been established to be applied to all financial sector companies listed on the São Paulo-SP Stock Exchange, B3. In this sense, companies that are part of the set of potential alternatives must meet a series of minimum requirements to be considered as members of the set of alternatives.

The definition of the filters used was based on applying a questionnaire to a group of four investors. They were asked to define the appropriate criteria for the initial filtering of the alternatives and the minimum acceptable performance in each of these criteria. This process was conducted using the questionnaire presented in Appendix I.

The investors consulted were between 28 and 39 years old, all with trading on the stock market for over three years and emphasizing using fundamentalist analysis for long-term investments. The investors selected were those with whom the researchers had easy access and freedom to dialogue but adequate to the profile described.

Only criteria/indicators referring to financial analysis and analysis by multiples were mentioned in the interviews. These two approaches are part of the group of four analyzes that constitute fundamentalist analysis. Thus, these were the criteria used in the present research. 
Thus, it is noteworthy that, at this same stage, no criteria/indicators related to economic analysis or fair price assessment of companies were mentioned, which are the other two approaches that integrate the fundamentalist analysis.

This fact is justified by the greater familiarity of the interviewees with the financial analyses and by multiples. Thus, this paper will only use the financial analysis and multiple analysis indicators, since investors cited only indicators related to these two analyses in their responses.

\subsection{Definition of criteria weights}

In stage 02, a search was conducted with investors following the Delphi method (Figure 3) to define the criteria and their weights (importance).

Figure 3: Items for defining criteria and weights.

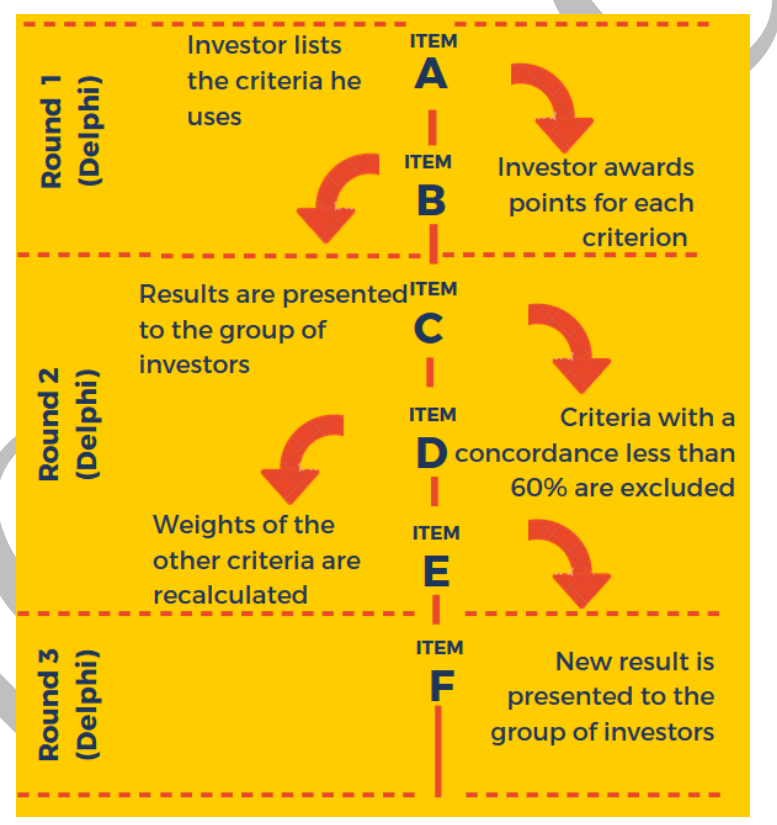

Source: The authors (2019)

In round 1, investors listed the criteria they used in the company analysis (item A) and then awarded points to each criterion they mentioned in the questionnaire to indicate the relevance of the criterion (item B). Thus, each criterion received a value between 0 and 100 points (0 less relevant, 100 more relevant). However, the sum of all the investor's points to all the criteria he mentioned should be equal to 100 (one hundred) points. The questionnaire used to define criteria and weights is presented in Appendix III. The first round results did not converge towards a consensus, and a second round is needed. In this round, all criteria 
mentioned and the global weights were presented to investors (item C), through the questionnaire contained in Appendix IV. They were asked whether they agreed with: a) the use of the criterion, b) the global weight assigned to the criterion. Also, to facilitate understanding of the terms used by the other participants in the study, we sent the glossary in Appendix II of this work to the investors.

As proposed by Santos (2001), we calculated the coefficient of agreement between investors' responses to the questionnaire presented in round 2. The coefficient was calculated separately for the concordance on the criterion's use and the weight attributed to the criterion. Equation 1 presents the method for calculating the concordance coefficient:

$$
\mathrm{Ca}=(1-\mathrm{Vn} / \mathrm{Vt})^{*} 100
$$

Where: Ca: Coefficient of agreement, expressed in percentage; Vn: Number of experts disagreeing with the criterion or weight, as appropriate; Vt: Total number of specialists.

Using the methodology proposed by Santos (2001) to apply the Delphi method, the criteria that did not obtain a minimum agreement of $60 \%$ were eliminated from the model (item D), and their weights were redistributed among the remaining criteria (item E). The new weights of these criteria (adjusted weights) were established.

Round 3 of Delphi method check the investors' agreement on the adjusted weights, which, although accepted by the investors, did not obtain the minimum weight agreement assigned in round 2. Thus, the adjusted weights were presented to the investors through the questionnaire presented in Appendix V, where the investors were asked as follows: "If the following criteria were used, would you agree with the weights assigned to them?".

After round 03, all criteria and weights obtained a concordance coefficient higher than $60 \%$, ending this stage. In the case of the coefficient below $60 \%$, other rounds are necessary.

\subsection{Performance measurement}

The performance data of the alternatives in each of the criteria were obtained through three different sources: a) website for "Fundamentus" investors ("www.fundamentus.com.br"); b) website for "Investing" investors ("br.investing.com"); and c) websites of the selected companies, through the investor relations area - IR. 


\subsection{Aggregation of results}

For the aggregation of performances (step four), the PROMETHEE V method was chosen. The use of the PROMETHEE V method is justified because it allows the generation of a portfolio of alternatives, meeting this research's objective. The method also avoids that an alternative's great advantages in a single criterion compensate unlimitedly unsatisfactory results in the other criteria (Alencar \& Almeida, 2010). This characteristic is essential for this research since it is necessary to ensure that the shares have a good overall performance in the criteria since investors have indicated a group of criteria that, together, allow identifying the best shares of companies in the financial sector in B3.

Moreover, it is a robust method, developed based on the construction of overcoming relationships of alternatives, allowing the adoption of quantitative and qualitative criteria simultaneously (Almeida \& Costa, 2002).

The possibility of adopting both types of criteria (quantitative and qualitative) is beneficial to the study, since future research, including economic analysis, may adopt qualitative criteria regarding the macroeconomic environment and, in this case, the model presented in this paper will remain valid and will allow expansion to include the other necessary criteria.

The first step of the PROMETHEE V method is to establish a ranking of alternatives". For this, we calculate the degree of preference $(\pi)$ of an alternative "a" over an alternative "b", according to Equation 2. We point out that for the calculation of the preference of "a" over "b" $(\mathrm{Pj}(\mathrm{a}, \mathrm{b}))$, we use the usual preference function of PROMETHEE.

$$
\begin{aligned}
& \text { 四 }
\end{aligned}
$$

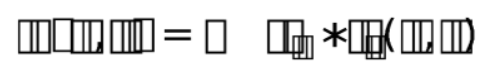

$$
\begin{aligned}
& \text { 때 } 1
\end{aligned}
$$

Where: $\pi(a, b)$ : Degree of preference of stock "a" over action "b"; J: Set of criteria; $W_{j}$ : Weight adopted to represent the importance of criterion $j ; P_{j}(a, b)$ : Preference of "a" over "b" according to the preference functions $\mathrm{F}$ and thresholds defined in the problem.

The next step in the ranking is to calculate the positive, negative and net flows for each share. The positive flow denotes how much an "a" stocks outperform the other stocks in the method's pairwise comparisons. The negative flow denotes how much "the other stocks outperform "a" stock in the method's pairwise comparisons. Finally, the net flow was calculated, indicating how much each stock exceeds the others and simultaneously is not 
exceeded. Equation 3 demonstrates the method used to calculate positive, negative and net flows.

$$
\begin{aligned}
& \text { - Positive flow: } \\
& \qquad \emptyset^{+}(a)=\frac{1}{n-1} \sum_{B \in A} \pi(a, b) \\
& \text { - Negative flow: } \\
& \emptyset^{-}(a)=\frac{1}{n-1} \sum_{B \in A} \pi(b, a) \\
& \text { - Net flow: } \\
& \varnothing(a)=\emptyset^{+}(a)-\emptyset^{-}(a)
\end{aligned}
$$

The first step of the method classified the shares in a ranking, through the net flow calculated for each share. However, this paper objective is related to the establishment of a portfolio of stocks, using an entire linear programming method (second step of the PROMETHEE V method).

Thus, we use the net flows to determine an optimal stock portfolio through the entire linear programming proposed by PROMETHEE V. The mathematical modeling used for the objective function of programming is expressed in Equation 4, adapted from Almeida; Almeida and Silva (2015).

$$
\operatorname{Max} \sum_{i=1}^{n} \emptyset_{i} \cdot x_{i}
$$

Where: $\emptyset_{i}$ : Net flow of stock "i"; $\mathrm{x}_{\mathrm{i}}$ : Variable that is associated with stock "i" and assumes the value 1 (one) if the stock is chosen to compose the portfolio or the value 0 (zero), otherwise; n: Total number of stocks analyzed, the case study was composed of 20 stocks (potential alternatives).

We have also implemented three programming restrictions. The first restriction determines that the number of shares chosen to compose the portfolio should be equal to 05 (five). PROMETHEE V stipulates that there should be a restriction on the number of alternatives to be chosen for the portfolio.

The other two restrictions are related to the average return of the alternatives (dividend yield) and the risk associated with each alternative (beta). The definition of the size of the portfolio and the choice of filters and minimum performance values 
were carried out by the four investors who participated in this work through a response to the questionnaire present in Appendix I. Equation 5, adapted from López e Almeida (2014), demonstrates the mathematical modeling of restrictions.

Equation 5: Constraints on integer linear programming of the PROMETHEE V method.

$$
\sum_{i=1}^{n} c_{i} \cdot x_{i} \approx B_{r}
$$

Where: $c_{i}$ : Contribution of stock " $\mathrm{i}$ " about restriction " $r$ "; $\mathrm{x}_{\mathrm{i}}$ : Associated variable that is associated with stock " $\mathrm{i}$ " and assumes the value 1 (one) if the stock is chosen to compose the portfolio and the value 0 (zero), otherwise; $B_{r}=$ Constant value referring to restriction " $r$ "; $n$ : Total number of alternatives ( 20 stocks). The parameter represented by " $\approx$ " can assume the values "=" (equal); " $\geq "$ (greater or equal) or " $\leq$ " (lesser or equal), according to the type of restriction.

We point out that to assess the clarity and quality of this questionnaire, before sending the form directly to investors, a pretest was conducted with two people who were not part of the investor group. Pretest participants demonstrated correct understanding of what was requested in the questionnaire.

\subsection{Capital allocation (entire linear programming)}

After establishing the portfolio of shares of financial sector companies using the PROMETHEE V multicriteria method, we performed a complementary step of entire linear programming in order to define, based on restrictions used exclusively in the capital allocation step, the amount of capital to be allocated in each share of the portfolio indicated by PROMETHEE V.

The linear programming's objective function was constituted by the adapted net flow of each alternative multiplied by a variable $X_{i}$, defined as the number of shares of alternative $A_{i}$ to be purchased, being $\mathrm{X}_{\mathrm{i}}$ a variable of the integer type. It is worth noting that alternatives with net flow less than or equal to zero do not contribute to the growth of the entire linear programming's objective function and, therefore, would be disadvantaged in capital allocation. 
Therefore, we used the method proposed by Almeida and Vetschera (2012) to make a mathematical transformation in the values of net flows to correct this problem and make all flows positive, using Equation 6, adapted from Almeida and Vetschera (2012), for this purpose.

Equation 6: Mathematical transformation of net flows.

$$
\emptyset_{a i}=\emptyset_{i}+\left|\emptyset_{\text {mín }}\right|+\alpha
$$

Where: $\varnothing$ ai: Liquid flow adapted from the alternative "i"; $\emptyset i$ : Original net flow of the alternative "i"; Ømín: Lowest net flow among all the " $i$ " alternatives; $\alpha=$ Constant of small value.

The software LINDO, version 6.1; Visual PROMETHEE, version 1.4; and Microsoft Excel, through the "Solver" feature, were used to aid calculations related to PROMETHEE V and the entire linear programming of the capital allocation step.

\section{RESULTS}

This topic presents the results obtained by way of an illustrative example. The results obtained are presented in the same sequence as the steps envisaged in the methodology.

\subsection{Selection of potential alternatives}

As mentioned in item 3.1 of the present work, step 01 consists of selecting the stocks that will be evaluated by the framework. To eliminate from the analysis companies that do not present a minimally stable financial health, two filters were applied to the 48 shares of companies in the financial sector listed in B3. The filters used were the following:

a) Price / Earnings: The share's P / E indicator must have a value less than or equal to fifteen (15);

b) Return on equity - Return on equity: The ROE indicator of the share must have a value equal to or greater than $10.5 \%$ a.a. (ten-point five percent per year). 
After applying the filters, we found that 28 (twenty-eight) companies did not meet investors' minimum requirements. Thus, the universe of potential alternatives was restricted to 20 actions, which we will name A1, A2, ..., A20.

\subsection{Definition of criteria and weights}

Table 6 presents all the criteria and final weights assigned by investors. These will be the criteria and weights adopted in the model proposed in our research. It took three rounds of the Delphi method to define the criteria and weights to be used in the model. Details of the results of each step are presented in Appendix VI of this article.

Table 6: Matrix of criteria and weights.

\begin{tabular}{|c|c|c|c|c|}
\hline Criterion & Code & Definition & Weight & Analysis logic \\
\hline Dividend Yield & $\mathrm{C} 1$ & $\begin{array}{l}\text { Dividend paid per stock divided by } \\
\text { the stock price is the annual return in } \\
\text { dividends that the company pays to } \\
\text { the stockholders. }\end{array}$ & $13 \%$ & Maximization \\
\hline Net Profit & $\mathrm{C} 2$ & $\begin{array}{l}\text { Sum of the company's income less } \\
\text { few expenses, costs, and payment of } \\
\text { taxes for the period (annual). }\end{array}$ & $24 \%$ & Maximization \\
\hline $\mathrm{ROE}$ & C3 & $\begin{array}{l}\text { Return on net equity, calculated by } \\
\text { dividing net income by net equity, } \\
\text { presents the percentage and annual } \\
\text { return, in profit, that the company } \\
\text { generates about the organization's net } \\
\text { equity. }\end{array}$ & $17 \%$ & Maximization \\
\hline 1 & $\mathrm{C} 4$ & $\begin{array}{l}\text { It represents all the company's } \\
\text { liabilities (gross debt) subtracted } \\
\text { from its cash holdings (cash on } \\
\text { hand). }\end{array}$ & $13 \%$ & Minimization \\
\hline Price/Profit & C5 & $\begin{array}{l}\text { Calculation: (Stock price } \mathrm{x} \text { total } \\
\text { number of stocks) / Profit in the } \\
\text { period. This number is to be } \\
\text { interpreted as the number of profit } \\
\text { years required for the accumulated } \\
\text { profit to equal the share price. }\end{array}$ & $9,25 \%$ & Minimization \\
\hline Current Liquidity & C6 & $\begin{array}{l}\text { Current Assets / Current Liabilities } \\
\text { indicates whether the company's }\end{array}$ & $8,25 \%$ & Maximization \\
\hline
\end{tabular}




\begin{tabular}{|l|l|l|l|l|}
\hline & & $\begin{array}{l}\text { receivables are higher or lower than } \\
\text { its short-term debts. }\end{array}$ & \\
\hline ROIC & C7 & $\begin{array}{l}\text { Return on invested capital expressed } \\
\text { in percent of the annual return on } \\
\text { capital invested in the company. }\end{array}$ & Maximization \\
\hline Net Margin & C8 & $\begin{array}{l}\text { Calculation: Net profit / net income. } \\
\text { Reflects how much profit remains for } \\
\text { the company in proportion to the } \\
\text { revenue. }\end{array}$ & Maximization \\
\hline
\end{tabular}

Source: The authors (2019)

\subsection{Performance matrix construction}

In the third stage of the research, the selected companies' performance matrix was built as potential alternatives to the method. The selected stocks' performances were measured and shown in the performance matrix (Table 7).

Table 7: Performance matrix of selected actions.

\begin{tabular}{|c|c|c|c|c|c|c|c|c|}
\hline $\begin{array}{l}\text { Criterion/ } \\
\text { Alternative }\end{array}$ & $\begin{array}{l}\text { Dividend } \\
\text { Yield }\end{array}$ & Net Profit (R\$) & ROE & $\begin{array}{ll}\text { Net } & \text { Debt } \\
(\mathrm{R} \$) & \\
\text { Million } & \end{array}$ & Price/Profit & $\begin{array}{l}\text { Current } \\
\text { Liquidity }\end{array}$ & ROIC & $\begin{array}{l}\text { Net } \\
\text { Margin }\end{array}$ \\
\hline A1 & $7,07 \%$ & 30.484 .000 & $12,74 \%$ & 241,13 & 4,13 & 1,95 & $10,29 \%$ & $18,29 \%$ \\
\hline A2 & $4,83 \%$ & 917.678 .000 & $20,40 \%$ & $54.446,94$ & 4,24 & 1,07 & $2,83 \%$ & $21,04 \%$ \\
\hline A3 & $5,64 \%$ & 221.060 .000 & $14,51 \%$ & 26436,27 & 7,96 & 1,05 & $2,46 \%$ & $16,29 \%$ \\
\hline $\mathrm{A} 4$ & $5,62 \%$ & 221.060 .000 & $14,51 \%$ & 26436,27 & 7,99 & 1,05 & $2,46 \%$ & $16,29 \%$ \\
\hline A5 & $2,08 \%$ & 63.274 .000 & $14,89 \%$ & 5070,67 & 8,04 & 1,08 & $3,08 \%$ & $10,96 \%$ \\
\hline A6 & $9,65 \%$ & 1.124 .620 .000 & $15,27 \%$ & 70152,81 & 8,07 & 1,1 & $2,35 \%$ & $15,45 \%$ \\
\hline A7 & $9,59 \%$ & 1.124 .620 .000 & $15,27 \%$ & 70152,81 & 8,13 & 1,1 & $2,35 \%$ & $15,45 \%$ \\
\hline A8 & $2,12 \%$ & 63.274 .000 & $14,89 \%$ & 5070,67 & 8,7 & 1,08 & $3,08 \%$ & $10,96 \%$ \\
\hline A9 & $8,69 \%$ & 1.124 .620 .000 & $15,27 \%$ & 70152,81 & 9,12 & 1,1 & $2,35 \%$ & $15,45 \%$ \\
\hline A10 & $5,56 \%$ & 429.092 .000 & $11,22 \%$ & 29063,26 & 9,37 & 1,12 & $1,86 \%$ & $52,24 \%$ \\
\hline A11 & $4,42 \%$ & 13.839 .400 .000 & $14,64 \%$ & 1317159,5 & 10,45 & 1,07 & $1,62 \%$ & $16,79 \%$ \\
\hline $\mathrm{A} 12$ & $8,82 \%$ & 9.522 .000 .000 & $18,89 \%$ & 11063 & 10,57 & 5,98 & $0,48 \%$ & $188,87 \%$ \\
\hline A13 & $7,84 \%$ & 9.522 .000 .000 & $18,89 \%$ & 11063 & 11,9 & 5,98 & $0,48 \%$ & $188,87 \%$ \\
\hline A14 & $2,76 \%$ & 20.438 .700 .000 & $16,13 \%$ & 1166171,24 & 12,55 & 1,1 & $1,87 \%$ & $10,07 \%$ \\
\hline A15 & $4,58 \%$ & 12.746 .200 .000 & $18,70 \%$ & 612762,97 & 12,57 & 1,14 & $1,82 \%$ & $20,05 \%$ \\
\hline A16 & $8,38 \%$ & 22.906 .600 .000 & $19,11 \%$ & 1416015 & 12,59 & 1,09 & $13,18 \%$ & $20,83 \%$ \\
\hline A17 & $4,34 \%$ & 12.746 .200 .000 & $18,70 \%$ & 612762,97 & 12,67 & 1,14 & $1,82 \%$ & $20,05 \%$ \\
\hline A18 & $4,04 \%$ & 12.746 .200 .000 & $18,70 \%$ & 612762,97 & 12,97 & 1,14 & $1,82 \%$ & $20,05 \%$ \\
\hline
\end{tabular}




\begin{tabular}{|l|r|r|r|r|r|r|r|r|}
\hline A19 & $2,68 \%$ & 20.438 .700 .000 & $16,13 \%$ & 1166171,24 & 14,22 & 1,1 & $1,87 \%$ & $10,07 \%$ \\
\hline A20 & $7,26 \%$ & 22.906 .600 .000 & $19,11 \%$ & 1416015 & 14,53 & 1,09 & $13,18 \%$ & $20,83 \%$ \\
\hline
\end{tabular}

Source: The authors (2019)

Thus, Table 3 presents the profile of potential alternatives regarding the performance of each share in the criteria defined by investors. From the data made available through this matrix, calculations were performed to apply the PROMETHEE method.

\subsection{PROMETHEE method application}

Using the performance matrix data, the degrees of preference were calculated in the pairwise comparison of stock performance in each criterion and the positive, negative and net flows of each stock. Then the ranking of the alternatives, presented in Table 8, was established.

Table 8: Ranking of alternatives.

\begin{tabular}{|l|l|l|l|l|l|}
\hline Position & Alternative & $\Phi$ & Position & Alternative & $\Phi$ \\
\hline 1 & A12 & 0,3790 & 11 & A17 & $-0,0103$ \\
\hline 2 & A16 & 0,3516 & 12 & A18 & $-0,0133$ \\
\hline 3 & A13 & 0,3272 & 13 & A14 & $-0,0822$ \\
\hline 4 & A20 & 0,2840 & 14 & A19 & $-0,1458$ \\
\hline 5 & A2 & 0,1843 & 15 & A3 & $-0,2010$ \\
\hline 6 & A6 & 0,0824 & 16 & A10 & $-0,2025$ \\
\hline 7 & A7 & 0,0585 & 17 & A4 & $-0,2249$ \\
\hline 8 & A15 & 0,0491 & 18 & A11 & $-0,2410$ \\
\hline 9 & A9 & 0,0107 & 19 & A5 & $-0,2901$ \\
\hline 10 & A1 & $-0,0099$ & 20 & A8 & $-0,3060$ \\
\hline
\end{tabular}

Source: The authors (2019)

Step II of applying the PROMETHEE V method consisted of establishing a portfolio of stocks among the potential alternatives, obeying the model's restrictions. Thus, through the questionnaire in Appendix I, investors proposed the following restrictions to the model: a) the portfolio must have a fixed size of 05 shares; b) the average Dividend Yield of the portfolio must be greater than or equal to $7.375 \%$ per year; and, c) The average risk (beta) of the portfolio must be equal to or less than 1.025. The net flow, dividend yield and risk (beta) associated with each alternative are presented in Table 9. 
Table 9: net flow, dividend yield e risk (beta) of each alternative.

\begin{tabular}{|l|l|r|r|r|r|r|r|}
\hline Alternative & Net flow & \multicolumn{1}{l|}{$\begin{array}{l}\text { Dividend } \\
\text { yield }\end{array}$} & Risk $($ beta $)$ & Alternative & Net flow & $\begin{array}{l}\text { Dividend } \\
\text { yield }\end{array}$ & \multicolumn{1}{l|}{$\begin{array}{l}\text { Risco } \\
\text { (beta })\end{array}$} \\
\hline A1 & $-0,0099$ & $7,07 \%$ & 1,00 & A11 & $-0,2410$ & $4,42 \%$ & 2,04 \\
\hline A2 & 0,1843 & $4,83 \%$ & 0,26 & A12 & 0,3790 & $8,82 \%$ & 1,22 \\
\hline A3 & $-0,2010$ & $5,64 \%$ & 0,56 & A13 & 0,3272 & $7,84 \%$ & 1,22 \\
\hline A4 & $-0,2249$ & $5,62 \%$ & 0,56 & A14 & $-0,0822$ & $2,76 \%$ & 1,45 \\
\hline A5 & $-0,2901$ & $2,08 \%$ & 1,00 & A15 & 0,0491 & $4,58 \%$ & 1,08 \\
\hline A6 & 0,0824 & $9,65 \%$ & 1,85 & A16 & 0,3516 & $8,38 \%$ & 1,27 \\
\hline A7 & 0,0585 & $9,59 \%$ & 1,85 & A17 & $-0,0103$ & $4,34 \%$ & 1,08 \\
\hline A8 & $-0,3060$ & $2,12 \%$ & 1,00 & A18 & $-0,0133$ & $4,04 \%$ & 1,08 \\
\hline A9 & 0,0107 & $8,69 \%$ & 1,85 & A19 & $-0,1458$ & $2,68 \%$ & 1,45 \\
\hline A10 & $-0,2025$ & $5,56 \%$ & 1,22 & A20 & 0,2840 & $7,26 \%$ & 1,27 \\
\hline
\end{tabular}

Source: The authors (2019)

After implementing the entire linear programming recommended by the PROMETHEE V method, a portfolio containing five stocks of companies in the financial sector was generated. Table 10 presents the portfolio generated by the method.

Table 10: Portfolio of stocks in the financial sector - PROMETHEE V.

\begin{tabular}{|c|c|c|c|}
\hline Alternative & Ranking position & Dividend yield & Risk (beta) \\
\hline A1 & $10^{\circ}$ & $7,07 \%$ & 1,00 \\
\hline A2 & $5^{\circ}$ & $4,83 \%$ & 0,26 \\
\hline A12 & $1^{\circ}$ & $8,82 \%$ & 1,22 \\
\hline A13 & $3^{\circ}$ & $7,84 \%$ & 1,22 \\
\hline A16 & $2^{\circ}$ & $8,38 \%$ & 1,27 \\
\hline & $\mathrm{A}-\mathrm{SUM}$ & $36,94 \%$ & 4,97 \\
\hline & $\mathrm{B}=(\mathrm{A} / 5)-\mathrm{MEDIA}$ & $7,388 \%$ & 0,994 \\
\hline
\end{tabular}

Source: The authors (2019)

As we can see, the portfolio's average dividend yield (7.388\% a.a) outperforms only $0.1763 \%$ above the minimum performance established in the constraint ( $7.375 \%$ a.a). Similarly, the portfolio beta risk (0.994) is only 3.03\% lower than the maximum acceptable risk set in the constraint (1.025).

As a result, the portfolio's performance is close to the minimum performance threshold set by investors. It is essential to highlight that a minimal change in the performance of one of the alternatives regarding dividend yield or risk may strongly restrict the universe of possible 
linear programming solutions so that, in extreme cases, there are no viable solutions to the problem. In this case, a higher threshold tolerance can be established to extend the number of possible solutions.

\subsection{Capital allocation (entire linear programming)}

After the portfolio was established, a linear schedule was implemented to define the amount of capital allocated to each of the stocks. To illustrate the operation of this step, we determined a hypothetical budget of $\mathrm{R} \$ 5,000.00$ (five thousand reais). This budget was considered in the programming by inserting a constraint in which the sum of the quotation value (price in $\mathrm{R} \$$ ) of each share multiplied by the variable $\mathrm{X}_{\mathrm{i}}$, which denotes the number of shares to buy from alternative $\mathrm{Ai}$, cannot exceed the maximum budget $(\mathrm{R} \$ 5,000)$. The quotation for each portfolio share on 06/18/2019 is: A12 (R\$ 11,97); A16 (R \$ 29,42); A13 (13,27); A1 (6,99); and A2 $(45,00)$.

In addition to the budgetary constraint, restrictions were imposed that impose a minimum share percentage of each share in the portfolio, aiming at investment diversification and risk reduction. Minimum participation percentages were determined by applying a questionnaire (Appendix I) to investors.

Thus, it was established that each alternative should participate with at least $10.5 \%$ (ten and a half percent) of the total available capital (budget). Equation 7 presents the complete modeling of integer linear programming for capital allocation.

Equation 7: Modeling for capital allocation.

Maximize

$0,0051 X_{1}+0,1992 X_{2}+0,394 X_{12}+0,3422 X_{13}+0,3666 X_{16}$

Subject to:

$6,99 X_{1}+45 X_{2}+11,97 X_{12}+13,47 X_{13}+29,42 X_{16} \leq 5000$

$6,99 \mathrm{X}_{1} \geq 525$

$45 \mathrm{X}_{2} \geq 525$

$11,97 \mathrm{X}_{12} \geq 525$

$13,47 X_{13} \geq 525$

$29,42 X_{16} \geq 525$

$\mathrm{X}_{1}, \mathrm{X}_{2}, \mathrm{X}_{12}, \mathrm{X}_{13}, \mathrm{X}_{16}$ entire.

Source: Authors, 2019. 
Next, Table 11 shows the result of the programming, indicating the number of shares to be purchased from each portfolio alternative. It can be observed that all restrictions were respected, and $\mathrm{R} \$ 4,998.93$ (four thousand, nine hundred and ninety-eight reais and ninety-three cents) were used from the total budget of $\mathrm{R} \$ 5,000.00$ (five thousand reais) by way of illustration.

Table 11: stock price of each alternative.

\begin{tabular}{|l|r|r|r|r|}
\hline Alternative & \multicolumn{2}{|l|}{$\begin{array}{l}\text { Stock price } \\
(\mathrm{R} \$)\end{array}$} & Quantity to buy & $\begin{array}{l}\text { Portfolio } \\
\text { percentage }\end{array}$ \\
\hline A12 & 11,97 & 240 & $\mathrm{R} \$ 2872,80$ & $57,46 \%$ \\
\hline A16 & 29,42 & 18 & $\mathrm{R} \$ 529,56$ & $10,59 \%$ \\
\hline A13 & 13,47 & 39 & $\mathrm{R} \$ 525,33$ & $10,51 \%$ \\
\hline A1 & 6,99 & 76 & $\mathrm{R} \$ 531,24$ & $10,62 \%$ \\
\hline A2 & 45,00 & 12 & $\mathrm{R} \$ 540,00$ & $10,80 \%$ \\
\hline
\end{tabular}

Source: The authors (2019)

It is important to highlight that $57.46 \%$ of the available capital was allocated in shares of the same company, alternative A12. occurred because the minimum holding restrictions required each stock's interest. After all, in only $10.5 \%$ of the total capital. As a result of this low percentage, most of the available capital was allocated to the alternative with the highest net flow.

The linear programming result maximized the use of alternatives with the higher net flow, as recommended in its objective function. However, the allocation of $57.46 \%$ of the available capital in a single financial asset may increase risks for the investor if the asset performs below the expected level.

Therefore, the restriction on the minimum holding of assets in the portfolio can be considered the most critical restriction of the capital allocation step. Decision-makers should carefully investigate their preferences regarding the mentioned percentage since the diversification of the portfolio and the correct distribution of capital among the assets will represent a dilution of financial risks for investors.

\subsection{Sensitivity analysis}

To evaluate the stability of the solution presented by the model, a sensitivity analysis of the weights adopted for all criteria was performed. For sensitivity analysis, an elevation and 
then a reduction of each criterion's weight by $15 \%$ (fifteen percent) of the original value was performed, changing the weight of a single criterion at a time. The difference in the high/reduced weight value is compensated proportionally in the weights of the other criteria to keep the sum of the weights always equal to $100 \%$.

As a result of the ranking's sensitivity analysis, Table 12 shows the positions occupied by each alternative considering all the analyzed scenarios.

Table 12: Sensitivity analysis of the ranking of alternatives.

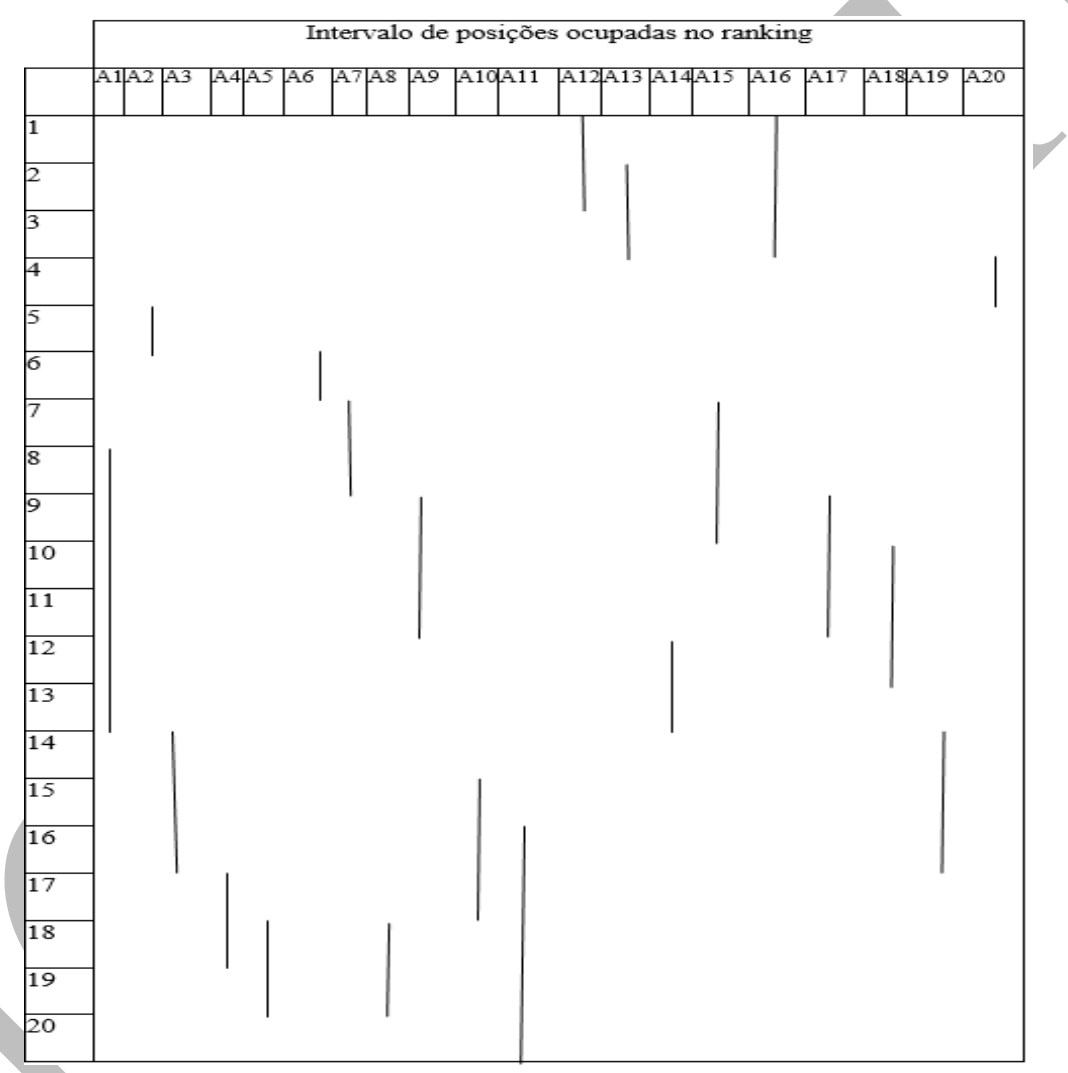

Source: The authors (2019)

We observed that the same alternatives were among the top six positions in all scenarios studied, which confirms the stability of the model. It should also be mentioned that the most considerable difference between criteria weights occurs between criteria $\mathrm{C} 2$ and $\mathrm{C} 8$, since $\mathrm{C} 2$ has weights about twice as large as criterion C8.

Given this, to increase the stability of the model, it is possible to establish a rule of maximum acceptable amplitude between the weights of two "Ci" criteria to make the distribution of the weights more uniform between the criteria.

In addition to the analysis of changes in the stock ranking, a sensitivity analysis was also carried out regarding changes in the portfolio generated due to the increase and reduction in the 
weightings of the criteria by $15 \%$ (fifteen percent). The change in the weights was similar to the methodology used for the sensitivity analysis of the ranking of alternatives.

In the sensitivity analysis of the portfolio, it was found that the portfolio of shares generated was confirmed in all scenarios analyzed, thus validating the robustness and stability of the model proposed in this study.

\subsection{Evaluation of results and investors' perception}

Based on the method's results and other sources of information that subsidize their decisions, investors were invited to evaluate the results generated by the framework proposed in this study.

Investors positively evaluated the results generated by the model. During the presentation of the results, it was found that each of the five shares indicated in the portfolio already had a stake in the portfolio of at least one of the investors who participated in the construction of the model.

It should be noted that investors mentioned that it would be relevant to build a model similar to the one developed in this study that also analyses companies from other economic segments, given that this research is restricted to companies from the financial sector.

\section{DISCUSSION}

The proposed model can support the stock selection process by investors, allowing for the consideration of multiple criteria. In this context, the investor can make a more rational choice, minimizing itself as distortions inherent in the process.

Also, the fact that the PROMETHEE V method is non-compensatory prevents a specific stock's negative or positive performance in a given criterion from being directly compensated, which contributes to a more satisfactory result. This characteristic is observed when we verify that the best position alternatives had the best performance among all the alternatives in at least one criterion and performance superior or close to the average performance of the potential alternatives in all the other criteria.

When addressing the portfolio issue, the model already selects the most appropriate stocks for the investor's preference structure. It should be noted that the alternatives selected to compose the portfolio do not correspond precisely to the first 5 (five) alternatives in the ranking of step I of PROMETHEE V. The alternative in the fourth place (A20) was not selected to compose the portfolio, because, if included, the risk restriction (beta) would not be met. So it 
would result in an average risk of 1.048 of the portfolio, which is higher than the maximum average risk indicated by investors (1.025). Alternative A1 (tenth position in the ranking) was selected instead.

Compared with the studies presented in Table 2, the proposed model differs when considering selecting a specific portfolio for companies in the financial segment. Thus, we seek to deepen the discussion on selecting the best stocks for a given investor profile, considering their reality.

In addition, it is observed that the literature focuses more on supporting the decisionmaking process for the short term, as Gomes (2018), Daibert (2016), Sant'Anna, Nogueira \& Rabelo (2012) and others, and few of them concentrate on supporting the decision-making process for long-term investors, as Malta \& De Camargos (2016), Paixão (2013) and Lyrio et al. (2015). The proposed model, which focuses on the long-term aspect, uses fundamentalist analysis considering technical data of the companies, originated directly from the management of the markets in which they are available.

Another point that deserves to be highlighted is that the literature focuses on supporting the selection of stock portfolios but does not propose a capital allocation to be carried out in the suggested portfolio, as Gomes (2018), Daibert (2016), Mehlawat (2016) and others. Thus, the proposed model, in addition to defining the best portfolio, requires the best configuration of capital allocation using entire linear programming and considering stock prices. In this way, the decision-maker receives much more information to make a decision then.

When deciding where to invest their money, the investor is faced with an extensive list of investment alternatives on the stock exchange. The proposed model supports this choice process by providing a portfolio of shares according to technical criteria, to which the investor can add others. In this way, the investor can filter the available options and consider those that maximize the possibility of gains. By proposing capital allocation, the model helps investors better understand how they can distribute the available funds among these portfolio alternatives, maximizing the earning potential. Such information is of great value, especially for long-term investors who invest in maintaining a long-term relationship with companies.

Finally, when proposing the allocation of capital, the model brings a more rational point of view to a process that can be quite complex for the investor. Thus, the results presented in this numerical application make evident the advantages that the model can bring to the investor, leaving the investor's final decision. 


\section{CONCLUSIONS}

The present research presents an investor decision support framework for the fundamentalist analysis approach, using the multicriteria decision support method PROMETHEE $\mathrm{V}$ and an entire linear programming model for capital allocation. The framework presented in this research fills the gap associated with the lack of a transparent investment analysis tool to establish an investment portfolio based on fundamentalist analysis.

Accordingly, the proposed model can establish a stock portfolio based on the performance of the fundamentalist indicators of companies in the financial sector. Also, the method is customizable according to the preferences and criteria adopted by each investor, which does not occur in most investment analysis tools available in the market.

Among the limitations of the research, we highlight using a single preference function to calculate the degree of preference in the pairwise comparison of the alternatives. We use only the usual function, which may not accurately reflect the behavior of preference in some criteria. We cite, as an example, the case of the criterion "Net Debt", whose logic of the criterion is minimization (the smaller, the better). Using the usual function for this criterion, a stock "a" that presents net debt only R \$ 0.01 (one cent) less than a stock " $\mathrm{b}$ " will be preferred strictly to "b".

We also noticed that the entire linear programming referring to capital allocation (the step after PROMETHEE V), while respecting the restrictions of minimum participation of $10.5 \%$ of each company in the total capital of the portfolio, attributed $57,46 \%$ of the available capital for the stock with the highest net flow in the portfolio, A12. This situation may increase the portfolio risk since a large part of its capital is associated with a single asset. Thus, future work may increase the minimum percentage of each company's participation in the portfolio or investigate the possibility of introducing new restrictions on the allocation of capital that result in a more uniform distribution of resources.

The use of the average risk in the portfolio average beta constraint (PROMETHEE V -

Part II) has limitations as there may be a correlation between the risks of two companies in the portfolio. Therefore, we suggest that future works investigate the possibility of using Markowitz's theory (1952) in the portfolio risk restriction.

Another limitation of the research is related to the fact that the model only deals with financial and multiples analyzes, not being performed economic analysis and fair price evaluation of the company. 
In this way, as possible future works, it is suggested that studies also include economic analysis and evaluation of the company's fair price. For economic analysis, we suggest studying the use of Porter's five forces model and SWOT matrix as input data for a multicriteria method to evaluate the economic aspects related to the firms under analysis.

Investors defined that the financial sector's portfolio of shares should be composed of five different shares in the present work. We suggest that future works study the ideal number of different assets for an investment portfolio composition. Finally, the development of a model that determines the percentage of participation of fixed income, variable income and funds in the total investment portfolio according to the investor's preferences is something that still needs to be studied.

Regarding the company's fair price valuation, we suggest the methodology proposed by Correia Neto and Brandão (2018), which uses Monte Carlo simulation to determine the fair price. We also emphasize that the decision-makers' parameters for application in this work are restricted to companies in the financial sector. However, the proposed model can be used to analyze other sectors, provided that experts from the analyzed segment of the model are consulted when defining the parameters. 


\section{REFERENCES}

Alencar, L. H., \& Almeida, A. T. (2010). A model for selecting project team members using multicriteria group decision making. Pesquisa Operacional, 30(1), 221-236. https://doi.org/10.1590/S0101-74382010000100011.

Almeida, A. T de, \& Costa, A. P. C. S. (2002). Modelo de decisão multicritério para priorização de sistemas de informação com base no método PROMETHEE. Gestão \& Produção, 9(2), 201-214. https://doi.org/10.1590/S0104-530X2002000200007.

Almeida, A. T. de, Almeida, J. A. de, \& SILVA, L. B. (2015). Uso do conceito c-optimal para seleção de portfólio de projetos na construção civil com base no método multicritério PROMETHEE V. Anais do XLVII Simpósio Brasileiro de Pesquisa Operacional. Porto de Galinhas, PE, Brasil.

Almeida, A. T. de, \& Vetschera, R. A. (2012). Note on scale transformations in the PROMETHEE V method. European Journal of Operational Research, 219, 198-200. https://doi.org/10.1016/j.ejor.2011.12.034.

Almeida, A. T. de. (2005). Modelagem Multicritério para Seleção de Intervalos de Manutenção Preventiva Baseada na Teoria da Utilidade Multiatributo. Pesquisa Operacional, 25(1), 69-81. https://doi.org/10.1590/S0101-74382005000100005.

Banihabib, M.E., Hashemi-Madani, FS. \& Forghani, A. (2017). Comparison of Compensatory and non-Compensatory Multi Criteria Decision Making Models in Water Resources Strategic Management. Water Resources Management 31, 3745-3759. https://doi.org/10.1007/s11269-017-1702-x

Belton, V; \& Stewart, J. (2002). Multiple Criteria Decision Analysis - an Integrated Approach. Kluwer Academic Publishers, London.

BOVESPA - B3 Bolsa Brasil Balcão. Por dentro da B3: Guia prático de uma das maiores bolsas de valores e derivativos do mundo. B3 Educação. Disponível em: http://www.b3.com.br/lumis/portal/file/fileDownload.jsp?fileId=8AE490CA6EF8051B016EF F8D43BD2064.

Brans, J. P., \& Mareschal, B. (2005). PROMETHEE methods. In Figueira, J., Greco, S. \& Ehrgott, M. Multiple Criteria Decision Analysis: State of Art, Surveys. (2005Springer, Boston, 133-161. 
Brans, J. P., \& Mareschal, B. (1992). PROMETHEE V: MCDM Problems with Segmentation Constraint. INFOR Journal: Information Systems and Operational Research, 30(2), 85-96. Carvalho, J. R., Carvalho, E. K., \& Curi, W. F. (2011). Avaliação da sustentabilidade ambiental de municípios paraibanos: Uma aplicação utilizando o método PROMETHEE II. Gestão \& Regionalidade, 27(80), 71-84. https://doi.org/10.13037/gr.vol27n80.1199.

Cavalcante, C., \& Almeida, A. T. (2005). Modelo multicritério de apoio a decisão para o planejamento de manutenção preventiva utilizando PROMETHEE II em situações de incerteza. Pesquisa Operacional, 25(2), 279-296. https://doi.org/10.1590/S0101-74382005000200007.

Correia Neto, J. F., \& Brandão, J. W. (2018). Valuation Empresarial: Avaliação de Empresas Considerando o Risco. $1^{\text {a }}$ ed, São Paulo: Atlas Book.

Costa, L. S., \& Duarte Junior, A. M. (2013). Uma metodologia para a pré-seleção de ações utilizando o método multicritério TOPSIS. Anais do XLV Simpósio Brasileiro de Pesquisa Operacional. Natal, RN, Brasil

Daibert, K. F. (2016). Priorização de critérios de decisão utilizados por investidores qualificados e especialistas para a compra e venda de ações. Dissertação de Mestrado. Universidade Federal Fluminense.

Gomes, I. O. (2018). Estratégias para operações de day trade na B3. Tese de Doutorado. Fundação Getulio Vargas.

Gomes, L. F. A., Rangel, L. A., \& Resende, R. C. (2015). Prioritization of Telecommunication Projects: Decision Analysis Using the Prométhée V Method. Revista Economia \& Gestão, 15(41), 311-332. https://doi.org/10.5752/P.1984-6606.2015v15n41p311.

Goumas, M. \& Lygerou, V. (2000). An extension of the PROMETHEE method for decision making in fuzzy environment: ranking of alternative energy exploitation projects. European Journal of Operations Research, 123. doi: https://doi.org/10.1016/S0377-2217(99)00093-4

Guarnieri, P. (2015). Síntese dos principais critérios, métodos e subproblemas da seleção de fornecedores multicritério. Revista de administração contemporânea, 19(1), 1-25. https://doi.org/10.1590/1982-7849rac20151109.

Hyde, K., Maier, H. R. \& Colby, C. (2003). Incorporating uncertainty in PROMETHEE MCDA method. Journal of Multi-Criteria Decision Analysis, 12, 245-259. doi: https://doi.org/10.1002/mcda.361 
Jeffreys, I. (2004). The Use of Compensatory and Non-compensatory Multi-Criteria. Smallscale Forest Economics, Management and Policy, 3(1), 99-117. doi: https://doi.org/10.1007/s11842-004-0007-0

Kobori, V. J. (2019). Análise Fundamentalista: Como obter uma performance superior e consistente no marcado de ações. $2^{a}$ ed, São Paulo: Atlas Book.

Le Téno, J. F. \& Mareschal, B. (1998). An interval version of PROMETHEE for the comparison of building products' design with ill-defined data on environmental quality. European Journal of Operations Research, 109, 522-529. doi: https://doi.org/10.1016/S0377-2217(98)00074-5

Lyrio, M. et al. (2015). Análise da implementação de uma estratégia de investimento em ações baseada em um instrumento de apoio à decisão. Contaduría y Administración, 60(1), 113143. https://doi.org/10.1016/S0186-1042(15)72149-2.

López, H. \& Almeida, A. T. (2014). Utilizando PROMETHEE V para seleção de portfólio de projetos de uma empresa de energia elétrica. Production, 24(3), 559-571. https://doi.org/10.1590/S0103-65132013005000045.

Luquet, M. (2007). Guia Valor Econômico de finanças pessoais. 2a ed. Globo Livros, Rio de Janeiro.

Luketic, K. (2019). XP Investimentos. Análise Fundamentalista, Carteira recomendada. Disponível em: https://analises.xpi.com.br/fundamentalista/carteiras/dividendos-julho-20192/. Acesso em 08/07/2019.

Malta, T. L. \& De Camargos, M. A. (2016). Variáveis da análise fundamentalista e dinâmica e o retorno acionário de empresas brasileiras entre 2007 e 2014. REGE-Revista de Gestão, 23(1), 52-62. https://doi.org/10.1016/j.rege.2015.09.001.

Marinoni, O. (2005). A stochastic spatial decision support system based on PROMETHEE.

International Journal of Geographical Information Science, 19(1), 51-68. https://doi.org/10.1080/13658810412331280176.

Markowitz, H. (1952). Portfolio selection. The Journal of Finance, 7(1), 77-91.

Mehlawat, M. K. (2016). Behavioral optimization models for multicriteria portfolio selection. Yugoslav Journal of Operations Research, 23(2), 279-297. https://doi.org/10.2298/YJOR130304028M 
Paixão, G. (2013). Modelo de seleção de portfólio de ações - Uma aplicação do método Analitic Hierarchy Process. Dissertação de mestrado. Pontífica Universidade Católica do Rio de Janeiro.

Tavares, A. L. \& Silva, C. A. (2012). A análise financeira fundamentalista na previsão de melhores e piores alternativas de investimento. Revista Universo Contábil, 8(1), 37-52. https://doi.org/10.4270/RUC.2012103

Vezmelai, A., Lashgari, Z., \& Keyghobadi, A. (2015). Portfolio selection using ELECTRE III: evidence from Tehran Stock Exchange. Decision Science Letters, 4(2), 227-236. https://doi.org/10.5267/j.ds1.2014.11.003

Vidotto, R. S. et al. (2009). O Moving Average Convergence-Divergence como ferramenta para a decisão de investimentos no mercado de ações. Revista de Administração Contemporânea, 13(2), 291-309. https://doi.org/10.1590/S1415-65552009000200008.

Roy, B. (1996). Multicriteria Methodology for Decision Aiding. Kluwer Academic Publishers, Netherlands.

Roy, B. (2005). Paradigms and Challenges. In Figueira, J., Greco, S. \& Ehrgott, M. (ed) Multiple Criteria Decision Analysis: State of Art, Surveys. Springer, Boston, pp 4-24.

Sant'anna, A. P., Rabelo, L. M., \& Nogueira, H. D. (2012). Comparação entre métodos multicritério em um modelo para avaliação da qualidade de ativos de renda variável. Revista de Finanças Aplicadas, 1, 1-21.

Santos, A. C. (2001). O uso do método Delphi na criação de um modelo de competências. Revista de Administração, 36(2), 25-32.

Souza, B. (2018). Emprego de Análise Multicritério como Auxílio na Tomada de Decisão no Descomissionamento de Dutos Submarinos. Tese de Doutorado. Universidade Federal do Rio de Janeiro.

Silva, V. B., Schramm, F.; Carvalho, H. R. (2014). O uso do método PROMETHEE para seleção de candidatos à bolsa-formação do Pronatec. Production, 24(3), 548-558. https://doi.org/10.1590/S0103-65132013005000048.

Xidonas, P., Mavrotas, G. \& Psarras, J. (2009). A multicriteria methodology for equity selection using financial analysis. Computers \& Operations Research, 36(12), 3187-3203. https://doi.org/10.1016/j.cor.2009.02.009. 